\title{
DETERMINATION OF MAINTENANCE FACILITY LOCATIONS AND IMPROVEMENTS TO SUPPORT THE OPERATION OF INDONESIAN NAVY IN NORTH NATUNA SEA BY THE FUZZY MCDM METHODS
}

\author{
Okol Sri Suharyo, Edy Widodo, Didit Herdiawan, Joko Purnomo \\ Indonesian Naval Technology College, STTAL Surabaya Indonesia
}

\begin{abstract}
Support the presence of the KRI elements it needs other supporting means such as Fasharkan (Maintenance and repair facilities) that serve as a supporter of logistics, especially repair and maintenance of KRI. The closest area of Fasharkan from the Sea of North Natuna today is Fasharkan Mentigi Lantamal IV Tanjung Pinang is approximately $510 \mathrm{Nm}$ surely will be an obstacle when the presence of the KRI element in the North Natuna Sea operating area is shaken because The distance of Fasharkan from the distant waters of North Natuna to carry out maintenance and repair. So it is necessary to one more location of Fasharkan to support the operation of the KRI elements in the territorial waters of North Natuna so that the operation of the KRI elements can be carried out well.In the selection of Fasharkan location has several factors that must be considered so that categorized have multicriteria in the election. So to accommodate Multicriteria divided into Technical Requirements \& Operational Requirements Then use the Fuzzy method MCDM (Multi-Criteria Decision Maker). Technical Requirement consisting of earthquake hazard, distance field operations (distance operations and ALKI 1), distance downtown (the distance of the center of the government and the settlement), and hydrography (depth, tidal, and speed of currents). While the Operational Requirement consists of the influence of other countries, threats (outside state threat and community conflicts), access transportation (military port and airport), supporting facilities (water facility, communication facilities, Electric facilities, transport facilities and sea flows), as well as operational costs. For the alternative location of Fasharkan consists of Lantamal XII Pontianak, Ranai Navy Base, and Tarempa Navy Base. Of the three alternative locations obtained the best alternative to the location of Fasharkan is Ranai Navy Base with the highest rank of 0.403 then Lantamal XII Pontianak with a value of 0.302 and Tarempa Navy base with a value of 0.295 .
\end{abstract}

Keywords: Sea of North Natuna, Fasharkan, determination of the type of Fasharkan, determining the location of the Fasharkan, Fuzzy MCDM.

\section{INTRODUCTION}

1.1 The Background of the Study

Maintenance and repair facilities

(Fasharkan) are part of the Indonesian Navy which has the duty and responsibility to provide material maintenance services, ship repair and manufacture of PC-class KRI (Patrol Craft) whose ship buildings are made of fiber or iron plates, the existence of Fasharkan is very much needed to support the maintenance and repair of $\mathrm{KRI}$. According to SKEP KASAL number Kep / 1771 / XII / 2013 concerning the standardization administration manual of the Navy base (PUM-7.03) that a Main Navy base (Lantamal) must have Fasharkan class $A$ whose ability is to be able to carry out maintenance and repairs up to the level of depo for all types of KRI, both ship building, ship machining, ship electricity, sewaco and ship weaponry.
Therefore, to support the readiness of $\mathrm{KRI}$ elements in the North Natuna Sea, it is necessary to have Fasharkan, which functions as a logistical supporter, especially for the improvement and maintenance of the KRI. According to data from the Ship Maintenance and Repair Office KOARMADA 1 the damaged ships and cannot be repaired organically should return to the nearest Fasharkan for the inspection and repair of the KRI ABCD case example which brought liquid logistics to support the KRI carrying out operations in Natuna. Jakarta due to engine damage, this certainly has an impact on the technical readiness of other ships in carrying out operations because the liquid logistics distribution of ships cannot be accommodated by KRI ABCD or Lanal Ranai. 
Table 1.1 KRI Data Operating in North Natuna sea 2015

\begin{tabular}{|c|c|l|}
\hline NO & KRI & \multicolumn{1}{|c|}{ Docking } \\
\hline 1 & Abcd & Main Engine (Injektor) \\
\hline 2 & Efgh & Propeller \\
\hline 3 & ljkl & AC \\
\hline 4 & Mno & Diesel Generator and anchor \\
\hline
\end{tabular}

Facts and conditions The closest Fasharkan mileage from the North Natuna Sea is Fasharkan Mentigi Lantamal IV Tanjung pinang about $510 \mathrm{Nm}$ will certainly be an obstacle if the presence of $\mathrm{KRI}$ in the North Natuna sea operating area is disturbed because Fasharkan's distance from the North Natuna sea is far to carry out maintenance and repairs. So it is felt that one more Fasharkan location is needed to support the operation of KRI in the North Natuna sea so that the operation of $\mathrm{KRI}$ can be carried out properly. These policies and facts form the basis of policies that support the importance of Fasharkan development in the operational area around the northern Natuna Sea.

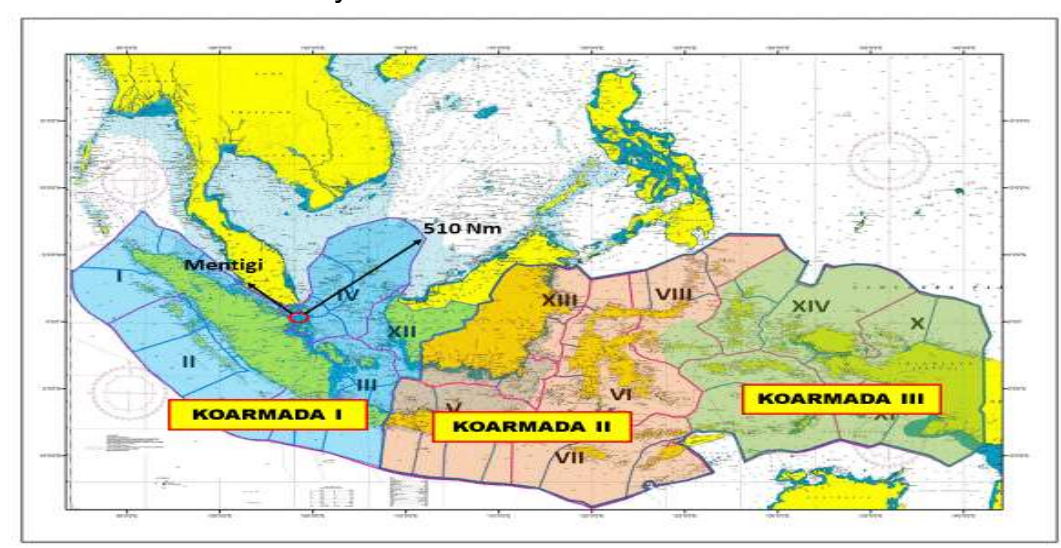

Figure 1.1 The working area

This final project research is expected to help provide advice and input to the leaders of the Indonesian Navy in choosing alternative locations for maintenance and repair facilities (Fasharkan) which will later be used to support $\mathrm{KRI}$ and other alusista operations in the North Natuna sea.

In this final project research, the author will determine the class or type of fasharkan that is used based on the highest wave height data in 2016,2017,2018 in North Natuna Sea and what kind of KRI criteria can carry out operations in North Natuna waters so that fasharkan has chosen can carry out its main tasks.

Furthermore, in the selection of an alternative, will be selected the best alternative
/ Mutually Exclusive will be chosen so that the chosen alternative can provide maximum benefits. Where the alternative choice of Fasharkan location in the North Natuna sea is Lanal Ranai Natuna islands, Lanal Tarempa Anambas Islands, and Lantamal XII Pontianak based on the distance of the base to the ability of KRI coverage areas operating in the North Natuna Sea, base capability and transportation access. This location determination process takes into account qualitative criteria namely safety, transportation access and supporting factors Fasharkan itself and criteria for quantitatively considering the distance to the operating area, distance to the city center, hydrographic conditions and earthquake natural disaster factors.

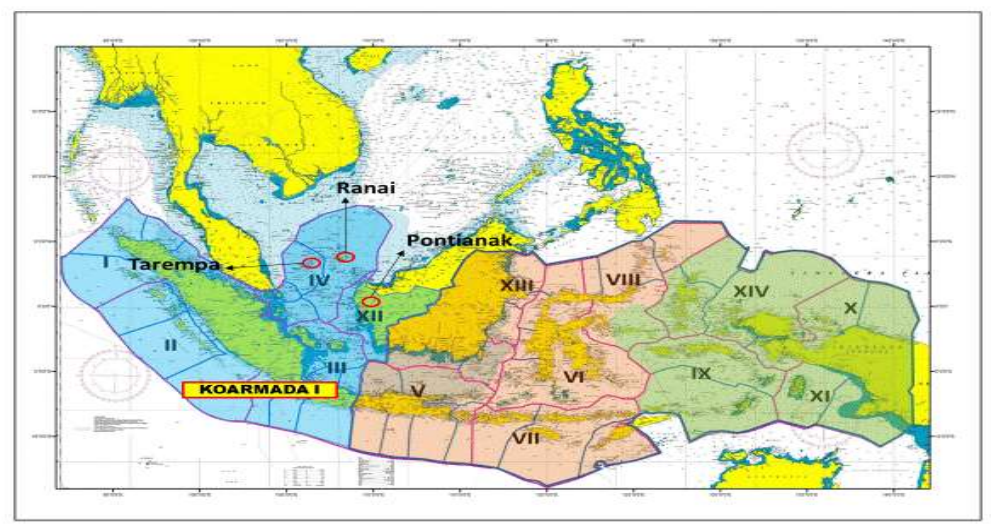

Figure 1.2 The Alternative location of Fasharkan 
Research on the location model has been carried out by previous researchers including the selection of the Mentawai Navy base location with the Borda method and the promethee method by Buyung Kurniawan (2015) with the results of the first order location being in Semebai Bay. Dodi Priyanggo (2016) in his research determined the alternative location of OMSP aid warehouse for natural disaster emergency response using the Set Covering and ANP method with the results of the analysis using priority weights with the highest weight of 0.237 located in the district of central Cilacap. Ali Nurul Jamil (2016) in his research on location determination and design of Arsenal warehouse facilities using the Fuzzy MCDM method and Systematic Layout Planing in the Koarmada I area with the results of Jakarta's Lantamal III being the best alternative with a value of 0.218

Decision support systems that are often used today usually use quantitative data so that they can deal with structured problems with definite data. But in reality on the ground, it is not uncommon to find qualitative data and contain elements of uncertainty. Uncertainty data like this are not appropriate to be used as a reference in decision making. So to overcome this we can use the concept of fuzzy logic. This is because the concept of fuzzy logic has a tolerance for inaccurate or uncertain data. In addition, in fuzzy logic data obtained in the field can be classified into qualitative data (Liang \& Wang 1999)

Fuzzy concept itself has been widely used as a model for building a decision support system, one of them is Fuzzy Multi Criteria Decision Making (FMCDM). In several studies stated that, MCDM is a method that refers to the process of screening, prioritizing, ranking, or choosing an alternative set. MCDM is very appropriate to be implemented in a multi-criteria case with all alternatives weighing criteria in nominal terms. But for the problem of determining the location of Fasharkan, not all alternatives have nominal weight criteria, for example security factors, transportation access, supporting facilities, etc. So to overcome this, the concept of Fuzzy is used for Multy Criteria Decision Making and is called Fuzzy MCDM which is considered very appropriate for the problem of criteria weighting that is uncertain (fuzzy) in his research.

Based on the case, in this thesis the author will solve the problem using the Fuzzy MCDM method as a model that is applied in order to obtain priority values in the design of a decision support system to determine the Fasharkan location which will be used to support KRI operations in North Natuna Sea with pay attention to several criteria including Technical requirements and Operational requirements. In addition, the Fuzzy MCDM method will overcome the multi-criteria problem in the process of determining this Fasharkan location and overcome the possibility of data that is qualitative in nature or contains uncertain elements.

\subsection{Formulation of the problem}

Based on the background of study that has been submitted, the problem statement or problem that can be raised is how to determine the location of maintenance and repair facilities to support the Navy's operations in the North Natuna Sea. Based on the problem statement, several Research Questions / research questions were prepared, such as:

a. How to identify the Fasharkan criteria in North Natuna sea.

b. How to determine the best alternative Fasharkan location to support KRI operations in the North Natuna sea.

\subsection{Objective of the Study}

After determining the background of the study which is then described in the formulation of the problem, the objectives of this Final Project are determined. The purpose of this study are as follows:

a. Formulating criteria and modeling the Fuzzy Multy Criteria Decision Making (MCDM) approach to obtain Fasharkan locations based on predetermined criteria.

b. Determine the location of alternative Fasharkan the best of the alternatives available around the North Natuna sea based on existing criteria with the Fuzzy Multy Criteria Decision Making (MCDM) method.

1.4. Significance of the Study

a. For Practitioners. Get the optimal type and alternative location options to get the Fasharkan location in the area around the North Natuna sea.

b. For Organizations. Provide input to the leaders of Indonesian navy in building the MEF's strength in the field of logistics supplies in the context of selecting the best Fasharkan location in the area around the North Natuna sea.

\subsection{Scope and Limitation}

In solving the problem so that it does not deviate from the objectives to be achieved and the problem is easily understood, the author only discusses the alternative locations available at the nearest Koarmada I Naval 
Base located in the North Natuna Sea operational area, namely Lantamal XII Pontianak, Lanal Ranai and Lanal Tarempa, which has the most possible criteria for the conditions of carrying out logistical support in the form of maintenance or repairs.

\subsection{Assumption}

a. $\quad$ There are no budget and land budget constraints needed to build a Fasharkan site.

b. There is land available at the Navy base or alternative locations

\section{LITERATURE REVIEW}

\subsection{Definition of Fuzzy}

Fuzzy logic is an appropriate way to map an input space into an output space. The starting point of the modern concept of uncertainty is the paper made by Lotfi A Zadeh in 1965, where Zadeh introduces a theory that has objects from the Fuzzy set that have imprecise limits and membership in the Fuzzy set, and not in the form of true logic (true) or false, but expressed in degrees. This concept is called fuzziness.

Barkeley in 1965. Fuzzy approach has advantages in the results related to human cognitive nature, especially in situations involving concept formation, pattern recognition, and decision making in an environment that is uncertain or unclear in other words Fuzzy approach method Reduces or minimizes results which is vague or uncertain.

\subsection{Multiple Criteria Decision Making (MCDM) \\ MCDM is a sub-discipline of} operations research that involves the analysis of a limited number of alternatives, which are explained in terms of evaluating criteria based on the values and preferences of decision makers (Guchhait, 2017). The MCDM method is a useful tool in many economic, manufacturing, material selection, military, construction, etc. issues that specifically play an important role in the field of investment decisions, project evaluation, evaluation of economic benefits, staff appraisal and so on (Gavade, 2014).

In MCDM, the use of conventional optimization methods is generally limited to only one selection criterion, where the selection taken is the choice that best meets the objective function. But the problems faced, especially those that are more practical, are not that simple.

Other advantages of MCDM can include: making decisions more transparent to others, providing means of structuring problems and working through information, providing focus for discussion, and helping people better understand problems from their own and others' perspectives. MCDM has been used at all levels of decision making relating to agriculture and the environment, from farmer level decisions to agricultural policy decision making. Environmental, economic, social and cultural considerations can be traded without changing all steps to the same unit (Dooley, Sheath, \& Smeaton, 2005).

MCDM provides an alternative to utilize objective and subjective considerations as a basis for decision making. There are two groups in MCDM, namely the decision-making group based on the selected attribute or often known as the Multiple Attribute Decision Making (MADM) and the group based on the synthesis of the choice attribute or often referred to as Multi-Objective Decision Making (MODM).

Multiple Objective Decision Making (MODM) uses an optimization approach, so to solve it must be sought first mathematical model of the problem to be solved. Then only maximized or minimized according to the mathematical model that has been obtained. Whereas the Multiple Attribute Decision Making (MADM) uses a selection approach by first determining the quantitative and qualitative attributes of the components to be selected.

\section{RESEARCH METHODS}

\subsection{Quantitative Research Approach}

Based on the focus and purpose of the study, the research approach used in this evaluation research is to use a quantitative approach, because this study is presented with numbers. This is in accordance with the opinion of (Arikunto, 2006) opinion that suggests quantitative research is a research approach that is widely demanded to reveal numbers, starting from data collection, interpretation of the data, and the appearance of the results.

In this study describes the stages of data collection, including: tests, questionnaires, interviews, observations, diaries, journals and so forth. In the quantitative method used closed tests and questionnaires in collecting, analyzing and interpreting data.

\subsection{Data Sources, Subjects, and Research Objects}

\subsubsection{Data sources}

Primary data sourced from interviews and questionnaires from 4 (four) selected experts namely from KOARMADA 1 . The 
experts provide an information that will be used as the main data source in the initial stages of research development.

In addition there are also several secondary data sources derived from books, journals, planning policies (Jakren), and a compilation of regulations related to research.

\subsubsection{Research subject}

The research subjects are people or objects that are observed with certain characteristics to be studied then a conclusion can be obtained from the learning process (Sugiyono, 2014). The subjects of this study were selected according to the needs of the Indonesian Navy which is the site of the study, including: main naval base and Armada I.

Table 3.1 Research Subject Plans

\begin{tabular}{|c|c|c|c|}
\hline N0 & RESPONDENT EXPERT & UNIT & TOTAL \\
\hline 1 & SOPS ARMADA1 & KOARMADA 1 & 1 \\
\hline 2 & SLOG ARMADA 1 & KOARMADA 1 & 1 \\
\hline 3 & DISHARKAP ARMADA 1 & KOARMADA 1 & 1 \\
\hline 4 & KRI COMMANDER & KOARMADA 1 & 1 \\
\hline
\end{tabular}

\subsubsection{Object of research}

The object of research is everything that is the core of the formulation of the problem in research (Sugiyono, 2014). The objects in this study are alternative locations in determining Fasharkan to support operations in North Natuna sea, 3 alternative locations are:
a. Lantamal XII Pontianak
b. Lanal Ranai
c. Lanal Tarempa

\subsection{Research Flow Chart}

The flow chart in this study is shown in Figure 3.2

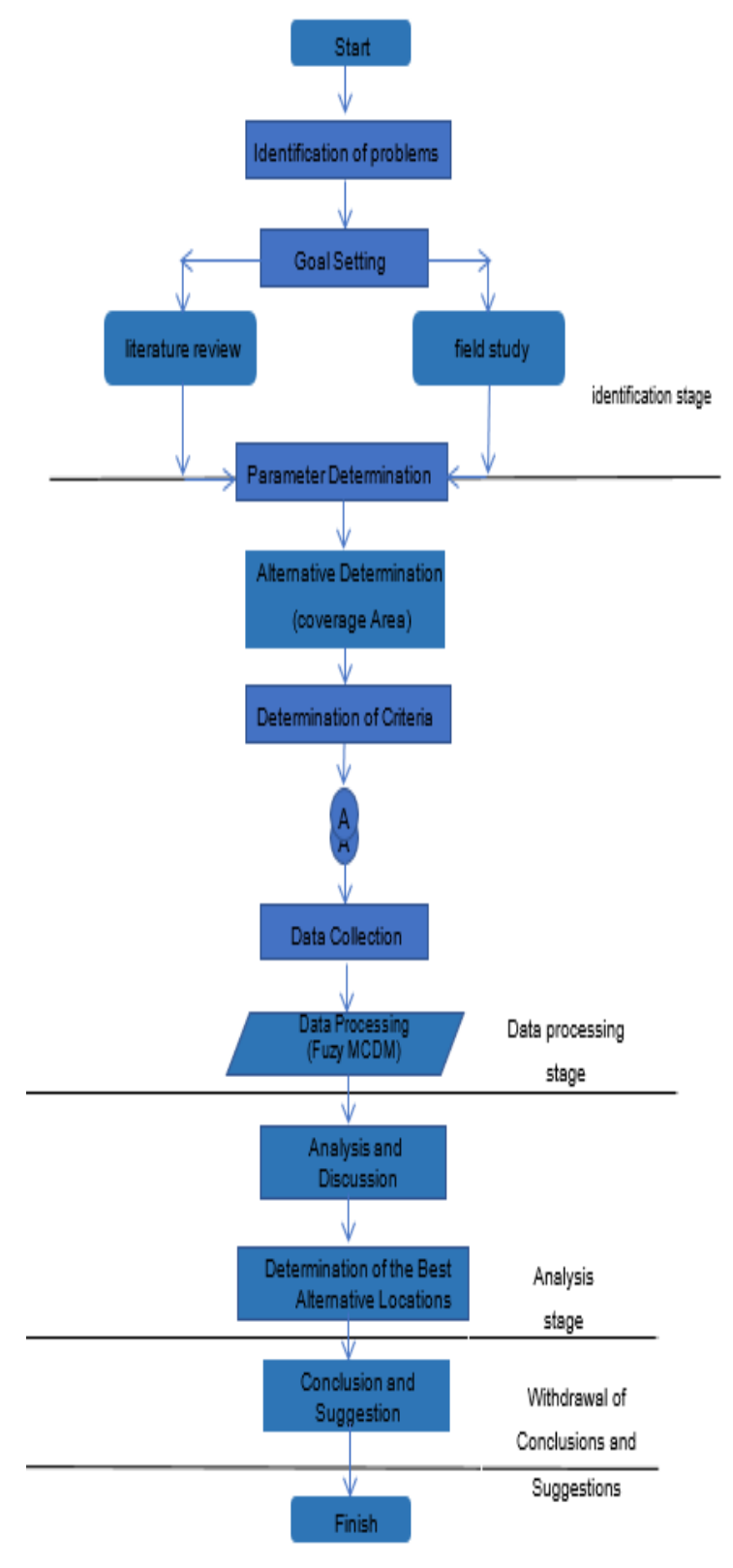

Figure 3.1 Research Flow Chart

\section{ANALYSIS AND DISCUSSION}

4.1 Data Processing

1. create a table of criteria level assessment results.

Labeling the results of weighting there are two scales in the assessment of the linguistic scale and numerical scale. Linguistic scale is divided into 5 levels of assessment, namely "very low", "low", "medium", "high" and "very high", while the assessment for numerical scale is between 1-10. In 
table 4.1 shows the results of the recapitulation of questionnaire and respondent data for the level of importance of operational requirements or qualitative criteria and the results of the questionnaire for each alternative based on quantitative criteria.

Table 4.1 Recapitulation of Expert Data Values for Criteria Level

\begin{tabular}{|c|c|c|c|c|c|c|}
\hline \multirow[t]{2}{*}{ NO } & \multirow[t]{2}{*}{ CRITERIA } & \multirow[t]{2}{*}{ SUB CRITERIA } & $\begin{array}{c}\text { EXPERT } \\
1 \\
\end{array}$ & $\begin{array}{c}\text { EXPERT } \\
2 \\
\end{array}$ & $\begin{array}{c}\text { EXPERT } \\
3 \\
\end{array}$ & $\begin{array}{c}\text { EXPERT } \\
4 \\
\end{array}$ \\
\hline & & & $\mathbf{N}$ & $\mathbf{N}$ & $\mathbf{N}$ & $\mathbf{N}$ \\
\hline & \multicolumn{2}{|c|}{ Operational Requirement } & & & & \\
\hline 1 & $\begin{array}{l}\text { effect on other } \\
\text { countries }\end{array}$ & & 7 & 7 & 7 & 6 \\
\hline \multirow{2}{*}{2} & \multirow{2}{*}{ Security } & $\begin{array}{l}\text { safe from } \\
\text { enemies }\end{array}$ & 8 & 8 & 7 & 8 \\
\hline & & $\begin{array}{l}\text { free of social } \\
\text { conflict }\end{array}$ & 7 & 7 & 7 & 8 \\
\hline \multirow{2}{*}{3} & \multirow{2}{*}{$\begin{array}{l}\text { Transportation } \\
\text { access }\end{array}$} & military port & 7 & 8 & 8 & 10 \\
\hline & & Airport & 7 & 7 & 8 & 8 \\
\hline \multirow{4}{*}{4} & \multirow{4}{*}{$\begin{array}{l}\text { Supporting } \\
\text { facilities }\end{array}$} & communication & 8 & 8 & 10 & 9 \\
\hline & & electricity & 9 & 8 & 8 & 10 \\
\hline & & water & 8 & 8 & 8 & 10 \\
\hline & & transport & 7 & 8 & 8 & 10 \\
\hline 5 & Operating costs & & 7 & 7 & 7 & 8 \\
\hline \multirow[t]{3}{*}{ NO } & \multirow[t]{2}{*}{ CRITERIA } & \multirow[t]{2}{*}{ SUB CRITERIA } & $\begin{array}{c}\text { EXPERT } \\
1 \\
\end{array}$ & $\begin{array}{c}\text { EXPERT } \\
2 \\
\end{array}$ & $\begin{array}{c}\text { EXPERT } \\
3 \\
\end{array}$ & $\begin{array}{c}\text { EXPERT } \\
4 \\
\end{array}$ \\
\hline & & & $\mathbf{N}$ & $\mathbf{N}$ & $\mathbf{N}$ & $\mathbf{N}$ \\
\hline & $\begin{array}{l}\text { Technical } \\
\text { Requirement }\end{array}$ & & & & & \\
\hline \multirow[t]{2}{*}{1} & \multirow{2}{*}{$\begin{array}{l}\text { Operating field } \\
\text { distance }\end{array}$} & ALKI 1 & 7 & 7 & 8 & 8 \\
\hline & & LCS & 9 & 8 & 8 & 8 \\
\hline \multirow{2}{*}{2} & \multirow{2}{*}{$\begin{array}{l}\text { City center } \\
\text { distance }\end{array}$} & \multirow{2}{*}{$\begin{array}{l}\text { City center } \\
\text { settlement }\end{array}$} & 6 & 6 & 6 & 5 \\
\hline & & & 5 & 6 & 6 & 5 \\
\hline \multirow{3}{*}{3} & \multirow{3}{*}{ Hydrography } & $\begin{array}{l}\text { The depth of } \\
\text { the sea }\end{array}$ & 9 & 8 & 8 & 8 \\
\hline & & tidal & 9 & 8 & 8 & 8 \\
\hline & & Flow Speed & 9 & 8 & 9 & 8 \\
\hline 4 & Earthquake thre & & 8 & 8 & 8 & 8 \\
\hline
\end{tabular}

2. Label the results of alternative rating ratings.

Labeling the results of alternative rating ratings can be seen in table
4.2 with the same scale as the evaluation criteria namely linguistic scale and numerical scale.

Table 4.2 Expert Data Recapitulation for Alternative Assessments Source : Expert Data Collection

\begin{tabular}{ccccccc}
\hline & CRITERIA & & EXPERT & EXPERT & EXPERT & EXPERT \\
\multirow{2}{*}{ NO } & SUB & ALTERNATIVE & $\mathbf{1}$ & $\mathbf{2}$ & $\mathbf{3}$ & $\mathbf{4}$ \\
\cline { 3 - 7 } & CRITERIA & & $\mathbf{N}$ & $\mathbf{N}$ & $\mathbf{N}$ & $\mathbf{N}$ \\
\hline \multirow{2}{*}{1} & $\begin{array}{c}\text { influence } \\
\text { on other }\end{array}$ & LANT XII & 6 & 6 & 6 & 3 \\
\cline { 3 - 7 } & LAN RANAI & $\mathbf{8}$ & $\mathbf{8}$ & $\mathbf{8}$ & $\mathbf{6}$ \\
\cline { 3 - 7 } & & & & &
\end{tabular}




\begin{tabular}{|c|c|c|c|c|c|c|c|}
\hline & countries & & $\begin{array}{l}\text { LAN } \\
\text { TAREMPA }\end{array}$ & 7 & 7 & 7 & 6 \\
\hline \multirow{6}{*}{2} & \multirow{6}{*}{ Security } & \multirow{3}{*}{$\begin{array}{c}\text { Safe } \\
\text { From } \\
\text { Enemie } \\
s\end{array}$} & LANT XII & 8 & 8 & 8 & 7 \\
\hline & & & LAN RANAI & 7 & 9 & 8 & 5 \\
\hline & & & $\begin{array}{l}\text { LAN } \\
\text { TAREMPA }\end{array}$ & 6 & 7 & 7 & 3 \\
\hline & & \multirow{3}{*}{$\begin{array}{l}\text { without } \\
\text { conflict }\end{array}$} & LANT XII & 8 & 7 & 7 & 3 \\
\hline & & & LAN RANAI & 8 & 8 & 8 & 7 \\
\hline & & & $\begin{array}{l}\text { LAN } \\
\text { TAREMPA }\end{array}$ & 7 & 8 & 8 & 7 \\
\hline \multirow{6}{*}{3} & \multirow{6}{*}{$\begin{array}{c}\text { Transporta } \\
\text { tion } \\
\text { Access }\end{array}$} & \multirow{3}{*}{$\begin{array}{c}\text { military } \\
\text { port }\end{array}$} & LANT XII & 7 & 7 & 7 & 7 \\
\hline & & & LAN RANAI & 6 & 6 & 6 & 6 \\
\hline & & & $\begin{array}{l}\text { LAN } \\
\text { TAREMPA }\end{array}$ & 5 & 4 & 5 & 3 \\
\hline & & \multirow{3}{*}{ Airport } & LANT XII & 7 & 7 & 7 & 8 \\
\hline & & & LAN RANAI & 6 & 7 & 7 & 8 \\
\hline & & & $\begin{array}{l}\text { LAN } \\
\text { TAREMPA }\end{array}$ & 5 & 5 & 4 & 3 \\
\hline \multirow{15}{*}{4} & \multirow{15}{*}{$\begin{array}{l}\text { Supporting } \\
\text { facilities }\end{array}$} & \multirow{3}{*}{$\begin{array}{l}\text { commu } \\
\text { nication }\end{array}$} & LANT XII & 8 & 8 & 8 & 8 \\
\hline & & & LAN RANAI & 6 & 6 & 6 & 5 \\
\hline & & & $\begin{array}{l}\text { LAN } \\
\text { TAREMPA }\end{array}$ & 5 & 5 & 5 & 3 \\
\hline & & \multirow{3}{*}{$\begin{array}{c}\text { electricit } \\
y\end{array}$} & LANT XII & 7 & 8 & 8 & 8 \\
\hline & & & LAN RANAI & 6 & 7 & 7 & 5 \\
\hline & & & $\begin{array}{l}\text { LAN } \\
\text { TAREMPA }\end{array}$ & 5 & 6 & 6 & 3 \\
\hline & & \multirow{3}{*}{ water } & LANT XII & 8 & 8 & 8 & 8 \\
\hline & & & LAN RANAI & 7 & 7 & 7 & 5 \\
\hline & & & $\begin{array}{l}\text { LAN } \\
\text { TAREMPA } \\
\end{array}$ & 6 & 4 & 4 & 3 \\
\hline & & \multirow{3}{*}{$\underset{t}{\text { transpor }}$} & LANT XII & 8 & 8 & 8 & 8 \\
\hline & & & LAN RANAI & 6 & 6 & 6 & 5 \\
\hline & & & $\begin{array}{l}\text { LAN } \\
\text { TAREMPA }\end{array}$ & 6 & 4 & 4 & 3 \\
\hline & & \multirow{3}{*}{$\begin{array}{c}\text { Sea } \\
\text { channel }\end{array}$} & LANT XII & 6 & 6 & 5 & 5 \\
\hline & & & LAN RANAI & 8 & 8 & 8 & 8 \\
\hline & & & $\begin{array}{l}\text { LAN } \\
\text { TAREMPA }\end{array}$ & 7 & 7 & 7 & 7 \\
\hline \multirow{3}{*}{5} & \multirow{3}{*}{$\begin{array}{l}\text { Operating } \\
\text { costs }\end{array}$} & & LANT XII & 5 & 6 & 7 & 6 \\
\hline & & & LAN RANAI & 7 & 8 & 8 & 8 \\
\hline & & & $\begin{array}{l}\text { LAN } \\
\text { TAREMPA }\end{array}$ & 7 & 7 & 6 & 7 \\
\hline
\end{tabular}

3. Determine the middle value of a fuzzy number.

Fuzzy middle numbers are numbers obtained from the sum of the values that appear at each level of the linguistic scale divided by the number of scales by formula (3.1). The calculation results are then used to make TFN.

4. Determine the lower, middle and top boundary values.

a. Medium linguistic level: for the lower value $c_{t}=1$ (as the lowest limit), the middle limit: $a_{t}=\frac{6+5}{2}=5,5(\mathrm{ct}$ level above), $b_{t}=a_{t}$ he level above it..

b. High linguistic level: value $\mathrm{C}_{\mathrm{t}}=6$ ( $a_{\mathrm{t}}$ low level), $a_{t}=\frac{7+7+7+7+7+7+7+8+8+8+8}{11}=$

7,36 ( $b_{t}$ medium level and $\mathrm{ct}$ level very high) dan $b_{t}=a$ very high level.

c. Very high level: $\mathrm{ct}=$ at high level, $a_{t}=\frac{9(5)+10(1)}{6}=$ 9,16 and $b t=10$. Calculation of experts 2, 3 and 4 using Microsoft Excel. 


\begin{tabular}{|c|c|c|c|c|c|c|c|c|c|c|c|c|c|}
\hline \multirow[b]{2}{*}{ NO } & \multirow{2}{*}{$\begin{array}{c}\text { LEVEL } \\
\text { LINGUISTICS }\end{array}$} & \multicolumn{3}{|c|}{ EX 1} & \multicolumn{3}{|c|}{ EX 2} & \multicolumn{3}{|c|}{ EX 3} & \multicolumn{3}{|c|}{ EX 4} \\
\hline & & qit & oit & pit & qit & oit & pit & qit & oit & pit & qit & oit & pit \\
\hline 1 & VERY LOW & & & & & & & & & & & & \\
\hline 2 & LOW & & & & & & & & & & & & \\
\hline 3 & MEDIUM & 1.0 & 5.50 & 7.4 & 1.0 & 6.0 & 7.7 & 1.0 & 6.0 & 7.2 & 1 & 5.3 & 8 \\
\hline 4 & $\mathrm{HIGH}$ & 5.5 & 7.4 & 9.2 & 6.0 & 7.7 & 9.0 & 6.0 & 7.2 & 9.0 & 5.3 & 8.0 & 9.8 \\
\hline 5 & VERY HIGH & 7.4 & 9.2 & 10.0 & 7.7 & 9 & 10 & 7.2 & 9 & 10 & 8.0 & 9.8 & 10.0 \\
\hline
\end{tabular}

Table 4.6 TFN Expert for assessing location criteria

Source: Data Processing

Table 4.7 TFN Expert for alternative assessments

Source: Data Processing

\begin{tabular}{|c|c|c|c|c|c|c|c|c|c|c|c|c|c|}
\hline \multirow[b]{2}{*}{ NO } & \multirow{2}{*}{$\begin{array}{c}\text { LEVEL } \\
\text { LINGUISTICS }\end{array}$} & \multicolumn{3}{|c|}{ EX 1} & \multicolumn{3}{|c|}{ EX 2} & \multicolumn{3}{|c|}{ EX 3} & \multicolumn{3}{|c|}{ EX 4} \\
\hline & & qit & oit & pit & qit & oit & pit & qit & oit & pit & qit & oit & pit \\
\hline 1 & VERY LOW & & & & & & & & & & & & \\
\hline 2 & LOW & & & & 1 & 4 & 5.7 & 1 & 4 & 5.6 & 1 & 3 & 5.4 \\
\hline 3 & MEDIUM & 1 & 5.6 & 7.4 & 4.0 & 5.7 & 7.5 & 4.0 & 5.6 & 7.5 & 3 & 5.4 & 7.5 \\
\hline 4 & $\mathrm{HIGH}$ & 5.6 & 7.4 & 10.0 & 5.7 & 7.5 & 9.0 & 5.6 & 7.5 & 10.0 & 5.4 & 7.5 & 10.0 \\
\hline 5 & VERY HIGH & & & & 7.5 & 9.0 & 10.0 & & & & & & \\
\hline
\end{tabular}

5. Determine the aggregate weights of each operational requirement criterion..

Respondents evaluate each selection criteria by using a linguistic scale to get the level of weight for the benefit of the criteria. Expert weight values for krteria on the linguistic scale shown in table 4.1 are then evaluated against TFN experts for criteria evaluation (table 4.6).

Then the calculation will get the aggregate weights for each operational requirement criterion, which will be used in defuzzification. The results of the average Aggregate Weight for the sake of operational requirements are shown in the following table:

Table 4.8 The aggregate weights of operational requirements

\begin{tabular}{|c|l|c|c|c|}
\hline \multirow{2}{*}{ NO } & \multicolumn{2}{|c|}{ CRITERIA } & \multicolumn{3}{c|}{ AVERAGE VALUE } \\
\cline { 3 - 5 } & & ct & at & bt \\
\hline \hline \multirow{2}{*}{1} & INFLUENCE ON OTHER & & & \\
& COUNTRIES & 4.625 & 6.900 & 8.790 \\
\hline 2 & SAFE FROM ENEMIES & 5.700 & 7.575 & 9.240 \\
\hline \multirow{2}{*}{3} & $\begin{array}{l}\text { WITHOUT COMMUNITY } \\
\text { CONFLICT }\end{array}$ & 5.700 & 7.575 & 9.240 \\
\hline 4 & MILITARY PORT & 6.375 & 8.025 & 9.290 \\
\hline 5 & AIRPORT & 5.700 & 7.575 & 9.240 \\
\hline \multirow{2}{*}{6} & COMMUNICATION & & & \\
& SUPPORT & 6.675 & 8.475 & 9.540 \\
\hline 7 & ELECTRICITY SUPPORT & 6.850 & 8.500 & 9.500 \\
\hline 8 & WATER SUPPORT & 6.375 & 8.025 & 9.290 \\
\hline 9 & TRANSPORT & 6.375 & 8.025 & 9.290 \\
\hline 10 & SEA CHANNEL & 7.000 & 8.800 & 9.950 \\
\hline 11 & OPERATING COST & 5.700 & 7.575 & 9.240 \\
\hline
\end{tabular}

6. Calculate the preference value of each alternative based on operational requirements criteria

To calculate the preference value of each alternative based on operational requirements criteria, an aggregate weight calculation is performed for each alternative for each operational requirement criterion to obtain an alternative preference value in the table as follows: 
Tabel 4.9 Value of Alternative Preference

\begin{tabular}{|c|c|c|c|c|c|c|c|c|c|c|c|}
\hline \multirow{2}{*}{ NO } & \multirow{2}{*}{ CRITERIA } & \multirow{2}{*}{ ALT } & \multicolumn{3}{|c|}{ RATA RATA } & \multirow{2}{*}{ NO } & \multirow{2}{*}{ CRITERIA } & \multirow{2}{*}{ ALT } & \multicolumn{3}{|c|}{ AVERAGE } \\
\hline & & & Qit & Oit & pit & & & & qit & Oit & pit \\
\hline \multirow{3}{*}{1} & \multirow{3}{*}{$\begin{array}{l}\text { INFLUENCE } \\
\text { ON OTHER } \\
\text { COUNTRIES }\end{array}$} & 1 & 2.500 & 4.975 & 6.950 & \multirow{3}{*}{6} & \multirow{3}{*}{$\begin{array}{l}\text { COMMUNICATION } \\
\text { SUPPORT }\end{array}$} & 1 & 5.575 & 7.425 & 9.750 \\
\hline & & 2 & 4.975 & 6.950 & 9.125 & & & 2 & 3.000 & 5.575 & 7.475 \\
\hline & & 3 & 4.975 & 6.950 & 9.125 & & & 3 & 2.500 & 4.975 & 6.950 \\
\hline & & & & & & & & & & & \\
\hline & & & & & & & & & & & \\
\hline \multirow{3}{*}{2} & \multirow{3}{*}{$\begin{array}{l}\text { SAFE FROM } \\
\text { ENEMIES }\end{array}$} & 1 & 5.575 & 7.475 & 9.750 & \multirow{3}{*}{7} & \multirow{3}{*}{$\begin{array}{l}\text { ELECTRICITY } \\
\text { SUPPORT }\end{array}$} & 1 & 5.575 & 7.425 & 9.750 \\
\hline & & 2 & 5.425 & 7.325 & 9.375 & & & 2 & 3.825 & 6.500 & 8.475 \\
\hline & & 3 & 3.325 & 5.900 & 7.950 & & & 3 & 2.500 & 4.975 & 6.950 \\
\hline & & & & & & & & & & & \\
\hline \multirow{3}{*}{3} & \multirow{3}{*}{$\begin{array}{l}\text { WITHOUT } \\
\text { COMMUNITY } \\
\text { CONFLICT }\end{array}$} & 1 & 4.475 & 6.350 & 8.600 & \multirow{3}{*}{8} & \multirow{3}{*}{$\begin{array}{l}\text { FRESH WATER } \\
\text { SUPPORT }\end{array}$} & 1 & 5.575 & 7.425 & 9.750 \\
\hline & & 2 & 5.575 & 7.325 & 9.750 & & & 2 & 4.975 & 6.950 & 9.125 \\
\hline & & 3 & 5.575 & 7.325 & 9.750 & & & 3 & 1.000 & 4.150 & 6.025 \\
\hline & & & & & & & & & & & \\
\hline \multirow{3}{*}{4} & \multirow{3}{*}{$\begin{array}{l}\text { MILITARY } \\
\text { PORT }\end{array}$} & 1 & 5.575 & 7.425 & 9.750 & \multirow{3}{*}{9} & \multirow{3}{*}{ TRANSPORT } & 1 & 5.575 & 7.425 & 9.750 \\
\hline & & 2 & 3.000 & 5.575 & 7.475 & & & 2 & 3.000 & 5.575 & 7.475 \\
\hline & & 3 & 1.750 & 4.550 & 6.500 & & & 3 & 1.000 & 4.150 & 6.025 \\
\hline & & & & & & & & & & & \\
\hline \multirow{3}{*}{5} & \multirow{3}{*}{ AIRPORT } & 1 & 5.575 & 7.425 & 9.750 & \multirow{3}{*}{10} & \multirow{3}{*}{ SEA CHANNEL } & 1 & 3.000 & 5.575 & 7.475 \\
\hline & & 2 & 4.425 & 7.025 & 9.100 & & & 2 & 5.575 & 7.475 & 9.750 \\
\hline & & 3 & 1.750 & 4.575 & 6.475 & & & 3 & 5.575 & 7.475 & 9.750 \\
\hline & & & & & & & & & & & \\
\hline \multirow{3}{*}{11} & \multirow{3}{*}{$\begin{array}{l}\text { OPERATING } \\
\text { COST }\end{array}$} & 1 & 3.400 & 6.050 & 8.100 & & & & & & \\
\hline & & 2 & 5.575 & 7.475 & 9.750 & & & & & & \\
\hline & & 3 & 5.175 & 7.000 & 9.125 & & & & & & \\
\hline
\end{tabular}

7. Calculate the value of the Fuzzy index from the results of the assessment of each alternative for the

By using the existing equation, the Fuzzy Index value is obtained Operational Requirements criteria.

Table 4.10 Value of Evaluation Formation

\begin{tabular}{|c|c|c|c|c|c|c|c|c|c|}
\hline \multirow{2}{*}{ ALT } & \multicolumn{10}{|c|}{ INDEX } \\
\cline { 2 - 10 } & $\mathbf{Y i}$ & Qi & Zi & Ti1 & Ti2 & Ui1 & Ui2 & Hi1 & Hi2 \\
\hline 1 & 29,34 & 54,29 & 80,35 & 3,82 & 21.13 & 3,09 & -33.10 & 2.76 & 5.35 \\
\hline 2 & 27,03 & 53,02 & 78,64 & 4,04 & 21.95 & 2,98 & -32.10 & 2.72 & 5.39 \\
\hline 3 & 19,04 & 44.56 & 68,46 & 4,43 & 21.10 & 2.91 & -30.12 & 2.38 & 5.18 \\
\hline
\end{tabular}

8. Calculates the utility value of each alternative for the Operational Requirements criteria

Before calculating the utility value, the defuzzification process is done using the centroid method. By using the equation in the calculation using the microsoft mathematic program.

Table 4.11 Defuzzyfication

\begin{tabular}{|c|c|c|c|c|c|}
\hline \multirow[t]{2}{*}{ NO } & \multirow[t]{2}{*}{ CRITERIA } & \multirow[t]{2}{*}{$\begin{array}{l}\text { DEFUZZYFICA } \\
\text { TION WEIGHT }\end{array}$} & \multicolumn{3}{|c|}{$\begin{array}{l}\text { DEFUZZYFICATION } \\
\text { ALTERNATIVE }\end{array}$} \\
\hline & & & ALT 1 & ALT 2 & ALT 3 \\
\hline 1 & $\begin{array}{c}\text { INFLUENCE ON OTHER } \\
\text { COUNTRIES }\end{array}$ & 6.771 & 4.808 & 7.016 & 7.016 \\
\hline 2 & SAFE FROM ENEMIES & 7.505 & 7.600 & 7.375 & 5.725 \\
\hline 3 & $\begin{array}{l}\text { WITHOUT COMMUNITY } \\
\text { CONFLICT }\end{array}$ & 7.505 & 6.475 & 7.600 & 7.600 \\
\hline 4 & MILITARY PORT & 7.897 & 7.600 & 5.350 & 4.322 \\
\hline 5 & AIRPORT & 7.505 & 7.600 & 6.850 & 4.266 \\
\hline 6 & COMMUNICATION SUPPORT & 8.230 & 7.600 & 5.412 & 4.808 \\
\hline 7 & ELECTRICITY SUPPORT & 8.275 & 7.600 & 6.266 & 4.808 \\
\hline 8 & FRESH WATER SUPPORT & 7.897 & 6.600 & 6.798 & 3.725 \\
\hline 9 & $\begin{array}{l}\text { TRANSPORT } \\
\end{array}$ & 7.897 & 7.600 & 5.350 & 3.725 \\
\hline 10 & SEA CHANNEL & 8.550 & 5.350 & 7.600 & 7.600 \\
\hline 11 & OPERATING COST & 7.505 & 5.878 & 7.600 & 7.100 \\
\hline
\end{tabular}


Table 4.12 Alternative Performance Value

\begin{tabular}{|c|l|c|}
\hline NO & ALTERNATIVE & $\mathbf{G i}$ \\
\hline 1 & LANTAMAL 12 PONTIANAK & 53,688 \\
\hline 2 & LANAL RANAI & 51,627 \\
\hline 3 & LANAL TAREMPA & 42,737 \\
\hline
\end{tabular}

9. Calculating the ranking value of each alternative based on Operational Requirements criteria. After all calculations are done, the ranking for alternatives based on operational requirements is as follows:

Table 4.13 Utility forming index

\begin{tabular}{|c|c|c|}
\hline NO & ALTERNATIVE & $\mathbf{G i}$ \\
\hline 1 & LANTAMAL XII PONTIANAK & $\mathbf{1 . 0 4 0}$ \\
\hline 2 & LANAL RANAI & $\mathbf{0 . 9 7 4}$ \\
\hline 3 & LANAL TAREMPA & $\mathbf{0 . 8 7 0}$ \\
\hline
\end{tabular}

Table 4.14 Alternative ranking on operational requirements criteria

\begin{tabular}{|c|c|c|}
\hline NO & ALTERNATIF & STi \\
\hline 1 & LANTAMAL XII PONTIANAK & 0,360 \\
\hline 2 & LANAL RANAI & 0,338 \\
\hline 3 & LANAL TAREMPA & 0,302 \\
\hline
\end{tabular}

From the ranking based on the Operation Requirement criteria above, it can be seen that from the three alternative locations for fasharkan development in order to support the Indonesian Navy operations in the North Natuna Sea, the first alternative is Pontianak Lantamal XII the best choice with a value of $\mathbf{0 . 3 6 0}$

10. Calculating alternative ranking values based on the Technical Requirements criteria

The calculation on this criterion is the same as the calculation on the operational requirements criterion and an aggregate weighting is obtained
Table 4.15 Aggregate technical requirements

\begin{tabular}{|c|l|c|c|c|}
\hline \multirow{2}{*}{ NO } & \multirow{2}{*}{ CRITERIA } & \multicolumn{3}{|c|}{$\begin{array}{c}\text { AVERAGE } \\
\text { WEIGHTED }\end{array}$} \\
\cline { 3 - 5 } & & ct & At & Bt \\
\hline 1 & DISTANCE OPS-ALKI1 & 5.7 & 7.6 & 9.24 \\
\hline 2 & DISTANCE OPS-LCS & 6.2 & 8 & 9.45 \\
\hline 3 & GOVERNMENT CENTER & 1 & 5.7 & 7.58 \\
\hline 4 & SETTLEMENT DISTANCE & 1 & 5.7 & 7.58 \\
\hline 5 & SEA DEPTH & 6.1 & 8 & 9.45 \\
\hline 6 & SEACURRENT SPEED & 6.5 & 8.6 & 9.7 \\
\hline 7 & TIDAL & 6.1 & 8. & 9.45 \\
\hline 8 & EARTHQUAKE THREATS & 5.7 & 7.6 & 9.24 \\
\hline
\end{tabular}

From the table of aggregate weights of the Technical Requirements criteria above, the defuzzification method is done using the centroid method. The defuzzification results are obtained for the Technical Requirements criteria in the following table, then unit normalization is performed.

Tabel 4.16 Defuzzyficaton Technical requirement

\begin{tabular}{|c|l|c|c|}
\hline \multirow{2}{*}{ NO } & CRITERIA & \multicolumn{2}{c|}{$\begin{array}{c}\text { CRITERIA } \\
\text { WEIGHT }\end{array}$} \\
\hline 1 & DISTANCE OPS-ALKI1 & 7.505 & 0.133 \\
\hline 2 & DISTANCE OPS-LCS & 7.883 & 0.139 \\
\hline 3 & GOVERNMENT CENTER & 4.758 & 0.084 \\
\hline 4 & SETTLEMENT DISTANCE & 4.758 & 0.084 \\
\hline 5 & SEA DEPTH & 7.811 & 0.138 \\
\hline 6 & SEA CURRENT SPEED & 8.490 & 0.150 \\
\hline 7 & TIDAL & 7.811 & 0.138 \\
\hline 8 & EARTHQUAKE THREATS & 7.505 & 0.133 \\
\hline
\end{tabular}

The weights of the Technical Requirements criteria above are then multiplied by the alternative Technical Requirement data of the Fasharkan location.

Table 4.17 Recapitulation of Technical requirements data weighting

\begin{tabular}{|l|c|c|c|c|c|}
\hline \multirow{2}{*}{ CRITERIA } & CRITERIA & \multicolumn{3}{c|}{ ALTERNATIVE } & \multirow{2}{*}{ TOTAL } \\
\cline { 3 - 5 } & WEIGHT & ALT 1 & ALT 2 & ALT 3 & VALUE \\
\hline DISTANCE OPS-ALKI1 & $\mathbf{0 . 1 3 2}$ & 135.000 & 32.000 & 110.000 & 277 \\
\hline DISTANCE OPS-LCS & $\mathbf{0 . 1 4 1}$ & 350 & 220 & 320 & 890 \\
\hline GOVERNMENT CENTER & $\mathbf{0 . 0 8 4}$ & 5 & 65 & 2 & 72 \\
\hline SETTLEMENT DISTANCE & $\mathbf{0 . 0 8 4}$ & 55.000 & 500 & 50 & 605 \\
\hline SEA DEPTH & $\mathbf{0 . 1 4 5}$ & 4 & 12 & 11 & 27 \\
\hline SEA CURRENT SPEED & $\mathbf{0 . 1 4 1}$ & 50 & 119 & 72 & 241 \\
\hline TIDAL & $\mathbf{0 . 1 4 1}$ & 0.400 & 0.400 & 0.200 & 1 \\
\hline EARTHQUAKE THREATS & $\mathbf{0 . 1 3 2}$ & 25 & 5. & 5 & 35 \\
\hline & & & & & \\
\hline
\end{tabular}




\begin{tabular}{|c|c|c|c|c|c|}
\hline & & NORM & ATION & JNITS & \\
\hline DISTANCE OPS-ALKI1 & 0.132 & 0.513 & 0.884 & 0.603 & 2.000 \\
\hline DISTANCE OPS-LCS & 0.141 & 0.607 & 0.753 & 0.640 & 2.000 \\
\hline GOVERNMENT CENTER & 0.084 & 0.067 & 0.905 & 0.028 & 1.000 \\
\hline SETTLEMENT DISTANCE & 0.084 & 0.091 & 0.826 & 0.083 & 1.000 \\
\hline SEA DEPTH & 0.145 & 0.148 & 0.444 & 0.407 & 1.000 \\
\hline SEA CURRENT SPEED & 0.141 & 0.793 & 0.506 & 0.701 & 2.000 \\
\hline TIDAL & 0.141 & 0.400 & 0.400 & 0.200 & 1.000 \\
\hline EARTHQUAKE THREATS & 0.132 & 0.286 & 0.857 & 0.857 & 2.000 \\
\hline & & NORM & ATION & UNITS & \\
\hline DISTANCE OPS-ALKI1 & 0.132 & 0.256 & 0.442 & 0.301 & 1.000 \\
\hline DISTANCE OPS-LCS & 0.141 & 0.303 & 0.376 & 0.320 & 1.000 \\
\hline GOVERNMENT CENTER & 0.084 & 0.067 & 0.905 & 0.028 & 1.000 \\
\hline SETTLEMENT DISTANCE & 0.084 & 0.091 & 0.826 & 0.083 & 1.000 \\
\hline SEA DEPTH & 0.145 & 0.148 & 0.444 & 0.407 & 1.000 \\
\hline SEA CURRENT SPEED & 0.141 & 0.396 & 0.253 & 0.351 & 1.000 \\
\hline TIDAL & 0.141 & 0.400 & 0.400 & 0.200 & 1.000 \\
\hline EARTHQUAKE THREATS & 0.132 & 0.143 & 0.429 & 0.429 & 1.000 \\
\hline & 1.000 & 0.244 & 0.468 & 0.288 & 1.000 \\
\hline
\end{tabular}

The data above uses a variety of units so it is needed for unit normalization. Furthermore, by using equation (3.27) ranking values can be calculated for the Technical Requirements criteria..

Tabel 4.18 Alternative ranking on the technical requirements criteria

\begin{tabular}{|c|c|c|}
\hline NO & ALTERNATIVE & Oti \\
\hline 1 & LANTAMAL XII PONTIANAK & 0.244 \\
\hline 2 & LANAL RANAI & 0.468 \\
\hline 3 & LANAL TAREMPA & 0.288 \\
\hline
\end{tabular}

Based on the Technical Requirements criteria in the table above it can be seen that of the three alternatives, the second alternative, Lanal Ranai has the highest ranking value with a ranking value of $\mathbf{0 . 4 6 9}$.

11. Calculate the total (final) ranking value of each alternative for the Operational Requirements and Technical Requirements criteria.

With equation (3.28) the total ranking can be calculated for the best alternative, it can be calculated:

$F T_{i}=\frac{S T_{i}+O T_{i}}{\Sigma V k} \quad$ where $\Sigma V k=2$

(quantitative and qualitative criteria)

$$
\begin{aligned}
& =\frac{0,360+0,244}{2} \\
& =0,302 \text { (for alternative } 1 \text { ) }
\end{aligned}
$$

Other alternative calculations using Microsoft Excel, so that the calculation results can be found in the table below.

Tabel 4.19 Total alternative ranking of locations for determining Fasharkan.

\begin{tabular}{|c|c|c|c|}
\hline NO & ALTERNATINE & Fi & RANK \\
\hline 1 & LANTAMAL XII PONTIANAK & 0.302 & II \\
\hline 2 & LANAL RANAI & 0.403 & I \\
\hline 3 & LANAL TAREMPA & 0.295 & III \\
\hline
\end{tabular}

\section{Choose the best alternative based on the highest ranking} value.

From table 4.27 above, it can be seen then choosing the best alternative with the highest total ranking value. The best alternative fasharkan location is the second alternative, Lanal Ranai with a total value of $\mathbf{0 . 4 0 3}$

\section{CONCLUSION AND SUGGESTION}

\subsection{Conclusion}

After carrying out the entire process of carrying out the final project, conclusions can be formulated based on the results of research methods and data processing and analysis, conclusions can be drawn as follows:

a. Based on the results of literature studies and consultations with experts, 19 criteria were obtained, consisting of 11 operational requirements and 8 technical requirements as consideration in determining Fasharkan location to 
support the operation of Indonesian Navy in North Natuna Sea..

b. The decision making process for determining the Fasharkan location can be modeled by applying the Fuzzy Multi Criteria Decision Maker model.

c. Proses The decision-making process in determining the location of Fasharkan was carried out by several experts as decision makers namely Kadisfaslanal, Asops KOARMADA I, Aslog KOARMADA I, Kadisharkap KOARMADA I, and Commander of KRI Bung Tomo so that each decision maker will provide a different subjective assessment of the alternative choice locations. there is. Fuzzy algorithm is applied to determining the location of Fasharkan, because it can eliminate the fuzziness or fuzziness of operational requirements criteria data which have high subjectivity values.

d. Based on data processing using the Fuzzy MCDM method, the best location for Fasharkan location placement is Lanal Ranai with the highest total ranking value, 0.403 then Pontianak Lantamal XII with a value of 0.302 and Lanal Tarempa with a value of 0.295

\section{ACKNOWLEDGEMENT}

The authors greatly acknowledge the support from STTAL Surabaya Indonesia for providing the necessary resources to carry out this research work. The authors are also grateful to the anonymous reviewers and journal editorial board for their many insightful comments, which have significantly improved this article.

Note : Because of Confidential, all of data is Simulation only (not real), and purpose educational only for Improving Model.

\section{REFERENCES}

Alshenqeeti, H. (2014). Interviewing as a Data Collection Method: A Critical Review. English Linguistics Research, 2.

Arikunto. (2006). Prosedur Penelitian Suatu Pendekatan Praktek. Jakarta.

Budi, D. (2015). Pemilihan Alternatif Lokasi Gudang Logistik Pendukung Dopusbektim Dengan Metode Analytic Network Process Dan Zero One Goal Programming.

Dooley, A. E., Sheath, G. W., \& Smeaton, D. (2005). Multiple Criteria Decision Making: Method Selection And
Application To Three Contrasting Agricultural Case Studies. New Zealand: NZARES Conference.

Gavade, R. K. (2014). Multi-Criteria Decision Making: An overview of different selection problems and methods. International Journal of Computer Science and Information Technologies, 5(4), 5643-5646.

Guchhait, A. (2017). Supplier Selection in A Supply Chain Using Multi-Criteria Decision Making Methods. American Journal of Engineering Research, 6(10), 338-345.

Hsieh, T.-Y. L.-T.-H. (2004). Fuzzy MCDM approach for planning and design tenders selection in public office.

Jamil, A. N. (2016). d. Penelitian dengan judul Penentuan Lokasi Dan Perancangan Fasilitas Warehouse Arsenal Menggunakan Metode Fuzzy MCDM dan Systematic Layout Planning (SLP).

Jantzen, J. (1998). Tutorial on Fuzzy Logic. Lyngby, Denmark: Departement Of Automation Technical University of Denmark.

Jantzen, J. (August 1998). Design of Fuzzy Controllers, Tech. Denmark: Department of Automation, Technical University of Denmark.

Johnston, M. P. (2014). Secondary Data Analysis: A Method of which the Time Has Come. Qualitative and Quantitative Methods in Libraries, 3, 619-626.

Kementrian Pekerjaan Umum. (2016). Peta Hazard Gempa Indonesia 2010 sebagai acuan dasar Perencanaan dan Perancangan Infrastruktur Tahan Gempa. Jakarta: Kementrian PU.

Keputusan Kasal. (2013). Pentunjuk Administrasi Standarisasi Pangkalan TNI Angkatan Laut.

Keputusan Panglima No 1312/2018. (n.d.). Prioritas Pembangunan Pulau Terluar.

Kurniawan, B. (2015). Model Pengambilan Keputusan Pemilihan Lokasi TNI AL Mentawai Dengan Pendekatan Borda Dan Promethee (Studi Kasus Lokasi Dermaga Dan Mako Lanal).

Kusumawati, H. S. (2006). Fuzzy Multy-Attribte Decision Making (Fuzzy MADM). Yogyakarta: Graha IImu.

Liang, \& Wang. (1999). A Hierarchy Fuzzy MCDM method for studying electronic marketing strategies in the information service industry. Jurnal of International Information Management, vol 8. 
Perkasal No 17. (2008). Tata Cara Penyimpanan Amunisi di Lingkungan TNI AL. Jakarta: TNI Angkatan Laut.

Perkasal Nomor 24. (2015). Kebijakan Strategis TNI AL tahun 2015 Sampai Dengan 2019. Jakarta: TNI Angkatan Laut.

Priyanggo, D. (2016). Analisa Penempatan Gudang Bantuan OMSP Tanggap Darurat Bencana Alam Menggunakan Metode Set Covering Dan ANP (Studi Kasus di Kabupaten Cilacap).

Rahmani, M., \& Ebrahimi, B. (2015). A MultiCriteria Decision Making Approach for Priority Areas Selection In Membrane Industry for Investment Promotion: A Case Study In Iran Marketplace. Journal of Industrial and Systems Engineering, 8(1), 41-61.

Sani, C. L. (2013). Data Collection Technique a Guide for Researchers in HUmanities and Education. International Research Journal of Computer Science and Information Systems, 40-42.
Sops ARMADA II. (n.d.). Peta Wilayah Kerja ARMADA I,II,II.

Stufflebeam, D. L. (2001). Evaluation Model. Michigan: John Wiley \& Sons.

Sugiyono. (2014). Penelitian Pendidikan: Pendekatan Kuantitatif, Kualitatif,dan $R \& D$. Bandung: Alfabeta.

Suharyo, O. S. (2015). Pengembangan Lokasi Pangkalan TNI Angkatan Laut Dengan Metode Fuzzy Dan Set Covering.

Undang-Undang Nomor 34. (2004). Tentara Nasional Indonesia. Jakarta: Indonesia.

Zadeh, L. A. (1965). Fuzzy Set. Information and Control.

Zadeh, L. (November 10, 2004). FUZZY LOGIC SYSTEMS: ORIGIN, CONCEPTS, AND TRENDS. Hong Kong: Computer Science Division Department of EECSUC Berkeley. 